\title{
CZYNY PRZEPOŁOWIONE BĘDACE WYKROCZENIAMI W UJĘCIU PRAWNYM I KRYMINOLOGICZNYM
}

Przedstawiciele różnych dyscyplin prawniczych interesują się kwestią odpowiedzialności karnej za czyny mniejszej wagi, zwane w jednych systemach prawnych wykroczeniami, w innych zaś drobnymi przestępstwami. Represja karna za tego typu czyny ma we wszystkich współczesnych systemach prawnych charakter masowy, zwłaszcza gdy uwzględni się nakładanie kar w trybie mandatowym, należące z reguły do uprawnień policji (milicji) i różnorodnych agend administracji ${ }^{1}$. Owe „drobne przestępstwa” nastręczają wiele problemów tak praktykom, jak i teoretykom prawa.

Odniesienie się do czynów zabronionych określonych jako wykroczenia nie jest możliwe bez ich umiejscowienia prawnego i kryminologicznego. Przestępczość w doktrynie kryminologicznej ${ }^{2}$ rozumiana jest jako zbiór czynów zabronionych ustawowo pod groźbą kary, a popełnionych na obszarze danej jednostki terytorialnej. Przestępczość jako zjawisko społeczne charakteryzuje się następującymi cechami:

- stanowi zagrożenie dla obowiązującego porządku prawnego,

- wyraża się we wzroście liczby osób, które popełniły przestępstwa w stosunku do ogółu ludności.

Wskazuje się, że rozpatrywana może być z punktu widzenia jej rozległości, intensywności, struktury i dynamiki, które determinowane są przez wiele czynników ${ }^{3}$.

Wobec powyższego trudno oprzeć się pokusie zadania pytania: gdzie należy szukać czynów, które niewątpliwie stanowią zagrożenie dla porządku prawnego, czyli wykroczeń? Uważam, że w ramach pojęcia ,przestępczość” wyodrębnić

\footnotetext{
A. Marek, Problem kodyfikacji prawa wykroczeń, Materiały Międzynarodowej Konferencji „Problemy współczesnego prawa wykroczeń", 8-11 października 1986 r., Karpacz, Wrocław 1986, s. 1.

B. Hołyst, Kryminologia, Warszawa 2007, s. 79.

http://pl.wikipedia .org (dnia 11.06.2009 r.)
} 
należy podkategorię ,wykroczeniowość”. Propozycja ta wynika chociażby z faktu, że większość popełnianych czynów zabronionych to nie przestępstwa, ale właśnie wykroczenia. Dane statystyczne KGP wskazują, że w 2008 r. ogółem nałożono 3832877 mandatów karnych w tym za wykroczenia z art. 119 kw. - 88 286, a za wykroczenia z art. 124 kw. - 1513. Wniosków o ukaranie wniesiono 392004 o wykroczenia z art. 119 kw. 51 742, a o wykroczenie z 124 kw. 13 688. Nie jest to pełen obraz popełnionych wykroczeń, pozostaje jeszcze tzw. ciemna liczba.

W swoim wystapieniu chciałabym wskazać nie na wszystkie czyny zabronione, ale na te, które współistnieją, można powiedzieć, na pograniczu dwóch gałęzi prawa, tj. prawa wykroczeń i prawa karnego, wskazując tym samym na ich bliską więź zarówno terminologiczną, jak i wynikającą z faktu przeplatania się procedur postępowania zarówno w sprawach o wykroczenia, jak i w sprawach o przestępstwa.

Wzajemne relacje pól przestępstw i wykroczeń mogą pozostawać ze sobą w stosunkach:

a) wykluczania się - to znaczy, że pola przestępstwa i wykroczenia bądź nie mają w ogóle punktów stycznych, bądź tylko stykają się ze sobą bez wzajemnego przenikania się (np. art. 119 kw. i art. 278 § 1 kk.);

b) zawierania się - to znaczy, że pole przestępstwa obejmuje swym zakresem pole wykroczenia (np. art. 177 kk.);

c) krzyżowania się - to znaczy, że pola przestępstwa i wykroczenia częściowo nakładają się na siebie (są wspólne), ale w pozostałej części nie pokrywają się ze sobą 4 (np. art. 88 kw. i art. 178a kk. w zw. z art. $10 \S 1$ kw.).

Jeżeli chodzi o czyny przepołowione, to precyzyjne ,przepołowienie” w ustawie dotyczy ich kategorii i powoduje, iż rozgraniczenie wykroczenia od przestępstwa jest wyraźne. Następuje to za pomocą kryteriów ostrych, jednoznacznych i w związku z tym należy tu mówić o wzajemnym wykluczaniu się obszarów prawa karnego i prawa wykroczeń. Relacja wykluczania się obszarów penalizacji jest zaprzeczeniem więzi polegającej na krzyżowaniu się zakresów objętych ustawowymi znamionami czynów karalnych, a zatem czyny przepołowione nie mają wspólnego pola desygnatów i nie tworzą zbiegów przepisów ustawy ${ }^{5}$. W ich wypadku zasadniczymi kryteriami rozgraniczającymi są:

- wartość przedmiotu czynu (np. art. 119 § 1 kw. i 287 § 1 kk.),

- wysokość szkody (np. art. 124 kw. i art. 288 kk.),

$4 \quad$ A. Gubiński, W kwestii rozgraniczenia..., s. 41.

5 W. Marcinkowski <http://www.prawo.lex.pl/czasopisma/prokurator/kilk_zag.html> grudzień 2008 r. 
- zawartość alkoholu we krwi lub wydychanym powietrzu (np. art. 87 kw. i art. 178a kk.).

Zatem czyn przepołowiony jest przepołowionym typem czynów zabronionych lub bitypem ${ }^{6}$. Jest więc takim typem czynu zabronionego, który inkorporuje dwie grupy czynów spełniających w zasadzie te same znamiona, przy czym jedna grupa będzie zakwalifikowana jako przestępstwo, druga zaś jako wykroczenie, po spełnieniu pewnego dodatkowego kryterium. Czyn przepołowiony jest więc w tym sensie podzielony na dwie części. Jednakże to dodatkowe kryterium, rzeczowe lub ocenne, wyznacza granicę pomiędzy przestępstwem a wykroczeniem? ${ }^{7}$.

Stan polegający na „przepołowieniu” czynów należy określić jako nowy wobec ustawy „zasadniczej”, jaką był kodeks karny z 11 lipca 1932 r. ${ }^{8}$ Przypomnieć należy, iż z jednocześnie ze wspomnianym kodeksem wydane zostało rozporządzenie Prezydenta RP Prawo o wykroczeniach (Dz.U. Nr 60, poz. 572). Należało je z jednej strony traktować jako dwa odrębne akty, $\mathrm{z}$ drugiej - były one ze sobą merytorycznie ściśle powiązane. Prawo o wykroczeniach stanowiło jakby przedłużenie norm prawa karnego w zastosowaniu do drobniejszych naruszeń. Jednakże z uwagi na swój charakter, czyli czynów „godzących bezpośrednio lub pośrednio w działalność administracji" i rodzaj organów uprawnionych do rozstrzygania w ich sprawach, bliskie były prawu administracyjnemu. Stąd też dyskusje co do istoty wykroczenia. Proces kształtowania się kategorii czynów przepołowionych następował stopniowo. Jednakże śmiem twierdzić, iż w znacznym stopniu przyczynił się do uporządkowania czynów na zbrodnie, występki i wykroczenia.

Pierwszym krokiem, który niewątpliwie zapoczątkował wspomniany proces, była ustawa z 17 czerwca 1966 r. ${ }^{9}$ Wprowadziła ona odrębne zasady odpowiedzialności, różniące się w poważnym stopniu od zasad obowiązujących w odniesieniu do wszystkich innych wykroczeń. Wyrażały się one przede wszystkim we wprowadzeniu nieznanej prawu o wykroczeniach odpowiedzialności za usiłowanie oraz za pomocnictwo i podżeganie. Ponadto okres przedawnienia orzekania $w$ tych sprawach przedłużony został do 1 roku $^{10}$. Obok wprowadzania nowych stanów faktycznych do kodeksu wykroczeń dokonywano ustawowych zmian, jeżeli chodzi o wartość przedmiotu czynu. Była ona różna w zależności od stanu faktycznego albo rodzaju czynu. Za tym postąpiło zbliżenie zasad postępowania w sprawach o wykroczenia do procesu karnego.

Z łac. „bi-„-- występujący w złożeniach oznacza: dwa, na dwie części, dwa razy, dwu-, podwójnie, obustronnie, W. Kopaliński, Słownik wyrazów obcych i zwrotów obcojęzycznych, Warszawa 1985, s. 55; „typ” — oznacza tutaj ustawowy zespół znamion przestępstwa; według niektórych to ostatnie określenie jest bardziej precyzyjne. <http://pl.wikipedia.org/wiki/Czyn_przepołowiony> grudzień 2008 r.

M. Bojarski, W. Radecki, Oceny prawne obszarów stycznych wykroczeń i przestępstw, Wrocław 1989, s. 24. Dz.U. Nr 23, poz. 149.

J. Skupiński, Przekazanie niektórych drobnych przestępstw do orzecznictwa karno-administracyjnego, „Państwo i Prawo" 1967, z. 1, s. 106. 
Przekazywanie orzecznictwa niektórych drobnych przestępstw organom właściwym w sprawach o wykroczenia, jak już wspomniano, postępowało. Ta tendencja znalazła także swoje odzwierciedlenie w obowiązującej do dziś ustawie kodeks wykroczeń z 1971 r., ale także w szeregu ustaw tzw. szczególnych. Zapoczątkowane bowiem ustawą z 1966 r. powiększanie kategorii wykroczeń następowało nie tylko na skutek dokonywanych przeliczeń granicy oddzielającej wykroczenie od przestępstwa, lecz również poprzez poddanie regulacji prawa wykroczeń zachowań, które uprzednio częściowo były uregulowane przepisami prawa o wykroczeniach, a częściowo przepisami kodeksu karnego. Takie rozwiązanie przewidziane zostało np. w ustawie z 6 kwietnia 1984 r. o gospodarce energetycznej (Dz.U. Nr 21, poz. 96), w ustawie z 18 kwietnia 1985 r. o rybactwie śródlądowym (Dz.U. Nr 21, poz. 193).

Proces ten nie przebiegał, nazwijmy to, ,gładko”. Obok czynnika regulującego pozostawanie bądź też nie w określonej kategorii czynów (przestępstw lub wykroczeń), jakim była wartość przedmiotu czynu (500 zł), bez względu na nią do kategorii wykroczeń zaliczono niektóre czyny, takie jak np. ukrywanie przed nabywcą towaru czy odmowa sprzedaży towaru, znęcanie się nad zwierzętami (obecnie przestępstwo z art. 35 - ustawa z 21 sierpnia 1997 r. o ochronie zwierząt (Dz.U.

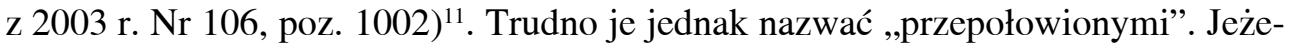
li natomiast odniesiemy się do wykroczeń przeciwko mieniu, to podstawowym kryterium przesądzającym o zakwalifikowaniu danego stanu faktycznego do przestępstwa bądź wykroczenia przeciwko mieniu, jest wartość rzeczy będącej przedmiotem czynu lub wysokość szkody, jaką poniósł pokrzywdzony. Obecnie jest to kwota 250 zł. Wyjątek stanowi wykroczenie wyrębu drzewa w lesie, gdzie granicę tę wyznacza kwota 75 zł. Stawka ta dotyczy także paserstwa umyślnego i nieumyślnego, którego przedmiotem jest pochodzące z kradzieży lub przywłaszczenia drzewo wyrąbane lub powalone w lesie. Okazuje się, że ustawodawca jednak nie jest konsekwentny w zakresie przepołowienia powyżej wskazanych czynów. Stąd też niekiedy, w zależności od rodzaju przedmiotu czynu lub okoliczności uszczegółowiającej zachowanie się sprawcy, wartość przedmiotu czynu nie ma znaczenia. W takich wypadkach jest on zawsze przestępstwem (art. $130 \mathrm{kw}$.). Zatem niezależnie od wartości przedmiotu czynu stanowią przestępstwa:

1) kradzieży, paserstwa i uszkodzenia rzeczy, jeżeli ich przedmiotem jest broń, amunicja, materiały i przyrządy wybuchowe (art. $130 \S 1$ pkt 2 kw.), dobra o szczególnym znaczeniu dla kultury (art. 294 kk.), program komputerowy (art. 278 § kk., art. 293 kk.), 
2) kradzieży, jeżeli jej przedmiotem jest energia, karta bankomatowa (art. 278 $\S 5 \mathrm{kk}$.) ${ }^{12}$, impulsy telefoniczne (art. $285 \mathrm{kk}$.), środki odurzające, substancje psychotropowe, mleczko makowe lub słoma makowa (art. 64 ustawy o przeciwdziałaniu narkomanii),

3) kradzieży z włamaniem ${ }^{13}$ (art. $131 \S 2$ kw.), kradzieży rozbójniczej albo rozboju (art. $130 \S 3 \mathrm{kw}$.$) .$

Skoro podstawowym kryterium rozgraniczającym wykroczenia przeciwko mieniu, będące czynami przepołowionymi (art. 119, 120, $122 \mathrm{kw}$.), od przestępstw jest wartość przedmiotu czynu, ${ }^{14}$, ważnym aspektem jest także określenie sposobu ustalenia tej wartości. Wartość rzeczy stanowiącej przedmiot czynu zabronionego powinna być oceniana (liczona) w odniesieniu do czasu popełnienia tego czynu i czasu wyrokowania, a nie w odniesieniu do czasu orzekania ${ }^{15}$, a także powinna być ustalona na podstawie obiektywnych dowodów, takich jak obowiązujące cenniki czy wyliczenia biegłych. Jest przy tym istotne, że w wypadku ciągłości działania przyjmuje się za podstawę oceny łączną wartość przedmiotów. W razie gdy łączna ich wartość przekroczy $250 \mathrm{zl} \mathrm{(w} \mathrm{odniesieniu} \mathrm{do} \mathrm{drzewa}-75 \mathrm{zl}$ ), w świetle art. $12 \mathrm{kk}$. mamy do czynienia z przestępstwem, chociażby poszczególne czyny dotyczyły mienia o niższej wartości ${ }^{16}$.

Czyny przepołowione godzące w mienie nie są jedynymi czynami, przy ocenie których należy brać pod uwagę kwestię przepołowienia. O tzw. przepołowieniu możemy również mówić przy wykroczeniu z art. 52a pkt $1 \mathrm{kw}$. z rozdziału „Wykroczenia przeciwko porządkowi i spokojowi publicznemu”, mającemu w zakresie nawoływania do popełnienia przestępstwa lub jego pochwalania swój odpowiednik w art. $255 \mathrm{kk} .{ }^{17}$ Do powyżej opisywanej kategorii należy także wykroczenie z art. 87 kw., które uległo przepołowieniu na skutek wprowadzenia ustawą z 14 kwietnia 2000 r. o zmianie ustawy kodeks karny z 15 grudnia 2000 r. do kk. występku prowadzenia pojazdu w stanie nietrzeźwości lub pod wpływem środka odurzającego (art. 178a).

Dla odpowiedzialności karnej na podstawie art. $278 \S 5 \mathrm{kk}$. nie ma znaczenia wartość zagarniętej przez sprawcę enargii. Przestępstwo określone w art. $278 \S 5 \mathrm{kk}$. nie ma bowiem odpowiednika w kodeksie wykroczeń i nie można zasadnie twierdzić, że zjawisko kontrawercjonalizacji związane z konstrukcją wykroczenia przewidzianego $\mathrm{w}$ art. 119 § 1 i 2 kw. odnosi się do przestępstwa kradzieży energii elektrycznej (por. wyrok SN z 26 lutego 2004 r., IV Kk.302/04, OSNKW 2004, poz. 413, s. 240); Kodeks karny. Część szczególna. Komentarz, t. 3. Komentarz do art. 278-363 kk., red. A. Zoll, Kraków 2006, s. 78 i n.

13 Do przestępstwa określonego w art. 279 kk., nie znajduje zastosowania regulacja zawarta w art. $119 \S 1$ kw. prowadząca do zjawiska kontrawercjonalizacji kryminalizacji zamachów na mienie. Patrz. Kodeks karny. Część szczególna. Komentarz, t. 3. Komentarz do art. 278-363 kk., red. A. Zoll, Kraków 2006, s. 84. R. Jancewicz, L.A. Niewiński, Tak zwane czyny „przepołowione”, „Wojskowy Przegląd Prawniczy” 2005, nr 2. Zob. wyrok SA w Lublinie z 29 marca 1999 r., Il Akz 117/98, Apel.- Lub. 1999, nr 2, poz. 16.

A. Marek, Prawo wykroczeń, Warszawa 1999, s. 154, za: R. Jancewicz, L.A. Niewiński, Tak zwane czyny „przepołowione”, „Wojskowy Przegląd Prawniczy” 2005, nr 2.

17 Art. $255 \S 1$. Kto publicznie nawołuje do popełnienia występku lub przestępstwa skarbowego, podlega grzywnie, karze ograniczenia wolności albo pozbawienia wolności do lat 2 . § 2. Kto publicznie nawołuje do popełnienia zbrodni, podlega karze pozbawienia wolności do lat 3. § 3. Kto publicznie pochwala popełnienie przestępstwa, podlega grzywnie do 180 stawek dziennych, karze ograniczenia wolności albo pozbawienia wolności do roku. 
Jak wskazują przedstawiciele doktryny, konstrukcja tych dwóch czynów oparta jest również na ich ,przepołowieniu”. Było to wynikiem wieloletnich dyskusji. Między innymi w uzasadnieniu do projektu kodeksu karnego w redakcji z sierpnia 1995 r. wskazywano na konieczność podjęcia decyzji o spenalizowanie jako przestępstwo kierowania pojazdem w stanie nietrzeźwości ze względu na społeczną szkodliwość takiego zachowania oraz wzrastającą liczbę wypadków drogowych z udziałem kierowców znajdujących się pod działaniem alkoholu. W uzasadnieniu zaś do projektu zmian kodeksu karnego, którym wprowadzono przepis art. 178a, zawarto informację, że dla karalności samego prowadzenia pojazdu w stanie nietrzeźwości lub pod wpływem środka odurzającego jest poważne zagrożenie, jakie ono stwarza dla osoby prowadzącej pojazd oraz innych osób.

Ten prosty, jak się wydaje, zabieg polegający na przesunięciu do kategorii wykroczeń stanów faktycznych, będących wcześniej przestępstwami lub odwrotnie, wywołał dyskusje trwające do chwili obecnej. Co rusz pojawiają się postulaty o wyłączenie czynów przepołowionych z kodeksu wykroczeń i, co za tym idzie, dokonanie zmian, jeżeli chodzi o odpowiedzialność za wykroczenia. Nie ma oczywiście zgody w tym zakresie wśród przedstawicieli doktryny. Stąd też są głosy za pozostawieniem takiego stanu, jaki jest obecnie, jeżeli chodzi o tę kategorię czynów.

Inną kwestią stanowiącą przedmiot dyskusji jest określenie owej kwoty granicznej pomiędzy przestępstwem a wykroczeniem. Lech Gardocki już w 1995 r. podnosił, iż (...) można mieć wątpliwości, czy ustawodawca nie przesunął tej granicy [do $250 \mathrm{zl}$ - przyp. autora] zbyt wysoko ${ }^{18}$. Andrzej Zoll natomiast podkreśla: „Przedtem kradzież była zawsze przestępstwem, niezależnie od wartości przedmiotu kradzieży. Oczywiście można było przyjąć znikome niebezpieczeństwo czynu, czyli dziś znikomą społeczną szkodliwość czynu, ale nie było przepisu stanowiącego, do jakiej kwoty kradzież jest wykroczeniem. Zresztą to jest pewien absurd, bo ile ,wyciągnie z kieszeni”, to tyle ma, ale zapewne chciał wziąć jak najwięcej i tylko dlatego, że pokrzywdzony miał akurat przy sobie tylko 20 zł to ma to być wykroczenie $^{19}$.

Istnieją dwa przeciwstawne stanowiska dotyczące utrzymania bądź nie czynów przepołowionych.

Ja stoję na stanowisku, iż czyny te powinny jednak podlegać ocenie z punktu widzenia kodeksu wykroczeń, a ich sprawca powinien być poddany postępowaniu w sprawach o wykroczenia; przekonanie to oparłam na ujęciu praktycznym. Umiejscowienie tych czynów w kodeksie karnym spowoduje, po pierwsze, wzrost kosz-

\footnotetext{
18 L. Gardocki, Najnowsze zmiany w Kodeksie karnym, „Monitor Prawniczy” 1995, nr 12, s. 353, za: R. Jancewicz, L.A. Niewiński, Tak zwane czyny „przepołowione”, „Wojskowy Przegląd Prawniczy” 2005, nr 2.

19 Wywiad z A. Zollem, „Aplikant Prokuratorski” 2004, nr 4, s. 5; R. Jancewicz, L.A. Niewiński, Tak zwane czyny „przepołowione”, „Wojskowy Przegląd Prawniczy” 2005, nr 2.
} 
tów ponoszonych przez organy ścigania. Mając w zakresie swojego działania zwalczanie przestępstw, z reguły muszą one podejmować czynności z urzędu (zasada legalizmu). Natomiast w razie wykroczeń ich reakcja na czyn opiera się na zasadzie oportunizmu (celowości), dającej możliwość poprzestania na zastosowaniu środków oddziaływania wychowawczego, np. pouczenia. Nowelizacja kodeksu postępowania w sprawach o wykroczenia z 2003 r. nadała postępowaniu zwyczajnemu charakter postępowania subsydiarnego, orzekanie bowiem $\mathrm{w}$ tym postępowaniu powinno następować tylko wówczas, gdy brak jest podstaw do rozpoznania sprawy w postępowaniu przyspieszonym lub nakazowym (art. 2 § 1a kpw.). W sprawach o wykroczenia funkcjonuje także postępowanie niesądowe - postępowanie mandatowe (art. 2 §, art. 95-102 kpw.). Skoro postępowanie zwyczajne jest ostatecznością, to przyjęte w noweli ustawowej rozwiązania pozwalają na szybkie i ekonomiczne rozstrzyganie w sprawach o wykroczenia. Daje to społeczne poczucie nieuchronności kary, szybkości w jej wymierzaniu (nakładaniu), towarzyszącej temu ekonomiczności, a co za tym idzie, poczucie sprawiedliwości, czego trudno doświadczyć w prowadzonych sprawach o przestępstwa. Po drugie, należy też liczyć się z tym, iż przejęcie przez sądy karne tak poważnej liczby spraw, które należy rozpatrzeć w ramach procedury karnej, może spowodować swoistą zapaść w zakresie orzekania w sprawach o przestępstwa. Po trzecie, o ile nie zmienia się społeczna szkodliwość czynów, to zmienia się punkt odniesienia w patrzeniu na nie, tzn. mają one stać się przestępstwami „mniejszego kalibru”, a jako takie na pewno podlegać będą instytucji umorzenia postępowania. Tym samym trudno będzie mówić o realizacji funkcji profilaktyczno-wychowawczej prawa karnego ${ }^{20}$, czy też funkcji represyjnej wyrażającej się w zaspokojeniu społecznego poczucia sprawiedliwości w związku z naruszeniem lub zagrożeniem dobra prawnego.

Nie są to argumenty natury dogmatycznej, gdyż w wypadku czynów przepołowionych mamy do czynienia, co do zasady, z jednorodnością, jeżeli chodzi o ustawowe znamiona. Nie ulega jednak żadnej wątpliwości, że za utrzymaniem obecnego status quo w przedmiocie czynów przepołowionych przemawia czynnik zapotrzebowania społecznego i argumenty natury pragmatycznej.

Trzeba sobie zdawać sprawę, że pokrzywdzenie czynami drobnymi, jakimi są analizowane wykroczenia (kradzieży, uszkodzenia cudzej rzeczy ruchomej itp.), może okazać się wielokrotnie daleko bardziej uciążliwe dla obywatela - dotykają go bezpośrednio - niż te opisywane w mediach (np. napady na banki, zamachy terrorystyczne). 
Kryminologia, co do zasady, poddawała i poddaje analizie przestępstwo. Skoro istotę wykroczenia obecnie należy analizować w kontekście istoty przestępstwa, uważam, że właściwe jest dlań stwierdzenie: „Czym innym jest schemat heurystyczny, obejmujący w badaniach trzy elementy: czyn, sprawcę, ofiarę a czym innym interpretacja czynu przestępczego (wykroczenia), traktowanego jako wynik oddziaływania na siebie elementów interakcji, czyli sprawcy i ofiary."21 Jeżeli zatem ,nakazem współczesnej nauki jest stworzenie możliwie najpełniejszego obrazu rzeczywistości społecznej z uwzględnieniem wszystkich rodzajów zagrożeń"22, niezbędne jest dogłębne zanalizowanie etiologii, sprawcy i ofiary wykroczenia.

W Wyższej Szkole Policji przeprowadzone zostały badania, które ukazały, że w grupie badanych policjantów około $9 \%$ funkcjonariuszy nie uchroniło się przed popełnionym czynem przepołowionym będącym wykroczeniem. Jest to o tyle znamienne, że powinni oni potrafić uchronić się przed czynami tej kategorii z racji styczności z nimi w toku pracy zawodowej.

W przypadku wykroczeń nie tylko nie można powiedzieć, że nauka o przestępcy rozwinęła się, przechodząc przez różne fazy interpretacji socjologicznych, psychologicznych, genetycznych na podstawie statystycznych interpretacji cech osób, które przekroczyły prawo, ale również, że nauka o ofierze jest młodą dyscypliną, skoro jej nie ma. ${ }^{23}$

Wiktymolodzy podkreślają znaczenie, jakie badania empiryczne przeprowadzane w odniesieniu do ofiary danego przestępstwa odgrywają w jego etiologii. Zwrócili uwagę, iż ustawodawstwo karne zajmuje się przede wszystkim psychiką sprawcy, zaniedbując badania procesów psychicznych w postępowaniu ofiary ${ }^{24}$. Często bowiem mamy do czynienia z czymś, co można nazwać ,winą” ofiary w kontekście jej zetknięcia ze sprawcą i samym przestępstwem. Rozumieć przez to należy zachowanie ofiary, która na skutek pewnych cech osobowości lub czynników sytuacyjnych zachowuje się nieostrożnie lub prowokacyjnie wobec późniejszego sprawcy. Może też przez swoje właściwości zewnętrzne (np. materialne, rodzinne, społeczne) czy wewnętrzne (np. biologiczne, fizyczne) wywoływać reakcje agresywne, mające na celu wyrządzenie szkody materialnej lub krzywdy fizycznej25. Wskazuje się w doktrynie na przypadki niezawinionego przyczynienia się ofiary do popełnianego czynu ${ }^{26}$.

21 B. Hołyst, Kryminologia, Warszawa 2007, s. 1259.

22 Ibidem, s. 1266.

23 Ibidem

24 Ibidem

25 J. Pecar, Rola osób trzecich w powstaniu przestępstwa, „Przegląd Penitencjarny i Kryminologiczny” 1973, nr 1 , s. 55-63.

26 Niezawinionym przyczynianiem się ofiary do popełnianego czynu zajmował się m.in. B. Hołyst w toku badań nad ofiarami zabójstw. B. Hołyst, Rola ofiary w genezie zabójstwa, „Państwo i Prawo” 1964, nr 11, s. 746-755. 
W związku z tym warto uznać za istotną koncepcję opisu sprawcy czynu przepołowionego i jego ofiary. Założyć należy, że tak jak w wypadku przestępstw analiza kryminologiczna modus operandi sprawcy i zachowań wiktymologicznych przyczyni się w znacznym stopniu do obniżenia poziomu zagrożenia czynami przepołowionymi będącymi wykroczeniami. Analiza teorii kryminologicznych w celu wskazania przyczyn popełniania czynów przepołowionych będących wykroczeniami pozwoliła mi na stwierdzenie, że nie ma możliwości tłumaczenia przyczyn wykroczeniowości tylko w ujęciu jednej teorii kryminologicznej. Zjawisko przestępczości (wykroczeniowości) nie jest zjawiskiem jednolitym, tak jak każde zachowanie ludzkie. Nie można też precyzyjnie określić zakresu wpływu na nie różnorodnych okoliczności społecznych, modyfikowanych dodatkowo przez samego człowieka. Nie można też pominąć w odpowiedzi na pytanie o genezę wskazanych czynów tych czynników, które proponują teorie zaprezentowane w tej pracy. Dopiero tak sformułowana „teoria” jest w stanie ukazać w miarę spójny obraz etiologii zachowań dewiacyjnych - wykroczeniowych.

Badania ankietowe 609 spraw o czyny przepołowione ukazują następujący obraz sprawcy czynu przepołowionego jako wykroczenie: zdecydowanie jest to mężczyzna

- 19-25 lat - 172 przypadki,

- 26-35 lat - 161 przypadków,

- 36-45 lat - 146 przypadków

kawaler; pracujący (141) i uczący się - (118), niemający nikogo na utrzymaniu, pracujący zawodowo (388); zarabiający do 1000 zł. (310).

Analiza akt spraw nie stanowiła jedynego źródła informacji w próbie opracowywania profilu sprawcy czynu przepołowionego będącego wykroczeniem. Wykorzystano również informacje z przeprowadzonych badań na 8018 funkcjonariuszach Policji. Okazało się, iż dane uzyskane $\mathrm{z}$ analizy akt spraw często są zbieżne $\mathrm{z}$ doświadczeniami funkcjonariuszy Policji w omawianym zakresie.

Opracowanie sylwetki kryminologicznej sprawcy czynu przepołowionego jest istotne nie tylko ze względu na działania wykrywcze, ale także prewencyjne, tak jak ma to miejsce w wypadku popełnianych przestępstw.

Przedstawione kwestie stanowią, powiedziałabym, czubek „góry lodowej” utworzonej z zagadnień z zakresu prawa materialnego i procedury wykroczeniowej wymagającej głębszej analizy i zainteresowania. 


\section{SUMMARY}

The article analyzes the so-called ,wobblers” qualified as misdemeanors. It emphasizes the importance of such acts to both substantive and procedural law. The article constitutes the author's contribution to the nearly 40-years-long discussion on the position of misdemeanors in the legal system. The author suggests that this category of criminal acts should be evaluated from the standpoint of criminology and uses the results of research conducted on this topic to draw a portrait of both perpetrators and victim of misdemeanors. 